\title{
GHRONIQUE-ANNOUNGEMENTS
}

L'Assemblee Générale de l'Institut International de Philosophie, réunie à Vienne à l'occasion du XIVe Congrès international de philosophie, rappelle solennellement que la liberté de pensée et d'expression est la condition indispensable de toute activité philosophique.

Elle fait appel à tous les organismes, nationaux et internationaux, qui seraient en mesure de venir en aide aux personnalités que la négation de cette liberté mettrait dans l'impossibilité d'exercer leurs fonctions dans l'enseignement ou la recherche philosophiques.

Elle déclare que l'Institut International de Philosophie, en raison de sa vocation, s'efforcera de contribuer à cette œuvre par tous les moyens en son pouvoir.

Au nom de l'Institut International de Philosophie, Raymond Klibansky, Président

The Canadian Philosophical Association will hold its annual meeting at York University (Toronto) on June 12, 13 and I4, I969. A complete time schedule will be provided later, but current plans include the following speakers and topics (listed alphabetically).

Robert A. Alexander, Waterloo University \& Waterloo Lutheran University.

The Problem of Metaphysical Doubt and Its Removal in Descartes. Guy Bouchard, Université Laval.

La tragédie et le tragique.

Mario Bunge, McGill University.

On Method in the Philosophy of Science.

I. Champagne, Collège des Jésuites, Québec.

Nature, conscience et histoire, dans l'idéologie allemande de Marx.

K. T. Fann, Florida State University.

Understanding Wittgenstein.

Paul P. Fitzgerald, University of Pennsylvania.

The Relativity of Time and Truth.

John R. Gallup, Université Laval.

La langue française contre Sartre.

Benoît Garceau, Université d'Ottawa.

Le sujet pratique et le sujet connaissant.

Garth Gillan, Canisius College.

Logos: Reason, Discourse and Symbol. 
Harold Greenstein, State University of New York (Brockport)

Minds, Motives and Dispositions.

Georges Hélal, Université de Montréal.

La cosmologie: un nouvel examen de sa nature et de sa raison d'être.

James R. Horne $\mathscr{E}$ Brian Hendley, University of Waterloo.

Religious expressions.

Robert A. Imlay, University of Toronto.

Is Descartes' Ontological Argument Really a Causal Argument for the Existence of God?

Fames $T$. King, Northern Illinois University.

Moral Consequences.

E. W. Kluge, University of California at Irvine.

Infinite Divisibility, Ontology and Spatial Relations.

Marvin Kohl, State University of New York (Fredonia).

Vagueness.

Guy LaFrance, Université d'Ottawa.

Les sources philosophiques de la sociologie française.

D. Lyons, Golorado State University.

Can Hart's Rationale for Legal Excuses Survive Determinism?

C. D. MacNiven, York University.

The Non-Equivalence of Act and Rule Utilitarianism.

Richard W. Momeyer, University of Washington.

Is Pleasure a Sensation?

H. A. Nielsen, University of Windsor.

History and Event.

Philip L. Peterson, Syracuse University.

Theory and Meaning.

Sergio D. Petraroja, University of Ottawa.

Joseph Fletcher's Situation Ethics: Cryptoantinomianism or Cryptolegalism?

Michael Ruse, University of Guelph.

Species' Definitions in Biology.

Evan Simpson, McMaster University.

Residual Scepticism.

Roger Smook, University of Guelph.

The Paradox of Identity: A Study in Semantical Alternatives.

A. T. Tymieniecka, Visiting Professor, University of Waterloo.

The Real Individual and the World Context of Actual Existence.

M. E. Williams, University of Western Ontario.

Nietzsche's Use of Paradox. 
George Yoos, Saint Cloud State College.

A Phenomenological Look at Metaphor.

The British Society for Phenomenology. The journal of the society will begin publication in the Autumn of 1969 under the editorship of Dr. W. Mays of the Department of Philosophy, University of Manchester. The journal will contain articles on phenomenology and related topics in the humanities. It will also contain discussion notes, reviews of recent books and a bibliographical section. The journal, which will be called The Fournal of The British Society for Phenomenology, will appear three times in the year and each issue will contain about Ioo pages. The yearly subscription will be 60 s. (members 45 s.) It will be published and distributed by Haigh \& Hochland Ltd., University Booksellers, 399 Oxford Road, Manchester, 13, to whom subscriptions should be sent. Articles, discussion notes and books for review should be sent to the Editor.

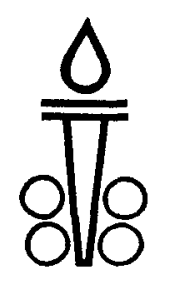

\section{THE PHILOSOPHER'S INDEX}

An International Quarterly Index

To Philosophical Periodicals

Editor: RICHARD H. LINEBACK Assistant Editor: RAMONA CORMIER

Editoral Board: William T. Blackstone, JAMES Collins, Alan

Donagan, Adolf Grünbaum, Patrick Suppes, Henry B. Veatch

The Philosopher's Index is an up-to-date quarterly index of articles from more than one hundred major American philosophical periodicals, selected foreign journals, and related interdisciplinary publications. More than five hundred articles of interest to philosophers are indexed by both subject and author in each issue.

Published in January, April, July, and October

Annual subscription $\$ 8.50$

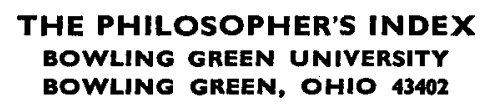

Printed in Belgium 